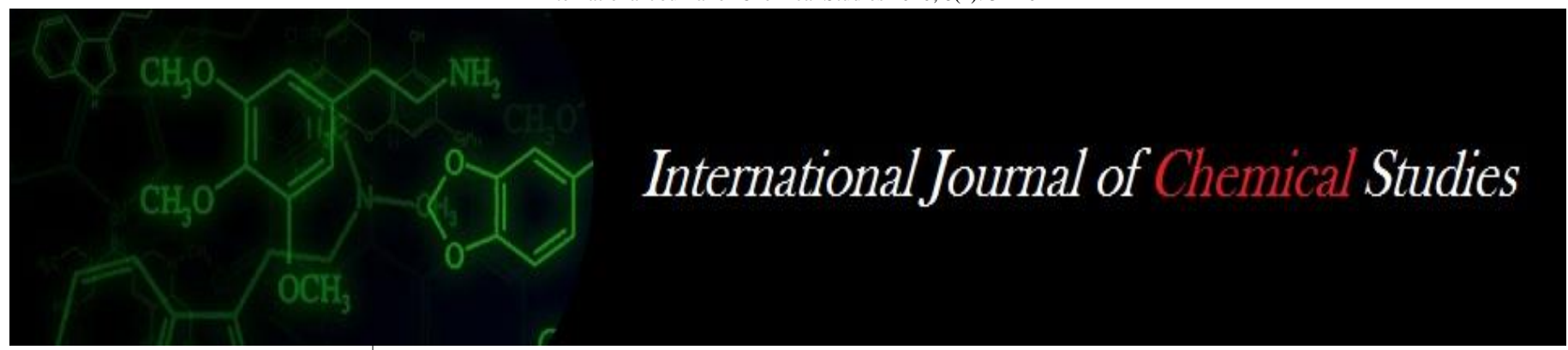

P-ISSN: 2349-8528

E-ISSN: 2321-4902

IJCS 2020; 8(1): 34-40

(C) 2020 IJCS

Received: 19-11-2019

Accepted: 23-12-2019

SS Rakesh

Research Scholar, AC\&RI,

Department of Environmental

Sciences, Tamil Nadu

Agricultural University,

Coimbatore, Tamil Nadu, India

Dr. PT Ramesh

Associate Professor, AC\&RI,

Department of Soil Science and

Agricultural Chemistry,

Tamil Nadu Agricultural

University, Killikulam,

Vallanad, Tamil Nadu, India

Dr. R Murugaragavan

Assistant professor,

Adiparasakthi Horticultural

College, Tamil Nadu Agricultural

University, Kalavai, Tamil

Nadu, India

Dr. S Avudainayagam

Professor, AC\&RI, Department

of Environmental Sciences,

Tamil Nadu Agricultural

University, Coimbatore, Tamil

Nadu, India

Dr. S Karthikeyan

Professor, AEC\&RI, Department

of Bio Energy, Tamil Nadu

Agricultural University,

Coimbatore, Tamil Nadu, India

Corresponding Author:

SS Rakesh

Research Scholar, AC\&RI,

Department of Environmental

Sciences, Tamil Nadu

Agricultural University,

Coimbatore, Tamil Nadu, India

\section{Characterization and treatment of grey water: A review}

\author{
SS Rakesh, Dr. PT Ramesh, Dr. R Murugaragavan, Dr. S Avudainayagam \\ and Dr. S Karthikeyan
}

DOI: https://doi.org/10.22271/chemi.2020.v8.i1a.8316

\begin{abstract}
Wastewater generated from households is categorised in to two types, greywater and black water, greywater constituting the largest flow. Greywater refers to the household wastewater generated from showers, washing machines and bathroom sinks excluding toilet wastes and that it has low pathogenic and organic contaminants. The greywater from residential apartment accounts for $50-70$ per cent. The composition of greywater varies greatly according to its origin (i.e., bathroom, laundry or kitchen greywater) and is influenced by the water quality of the locality. A variety of contaminants including acidic and alkaline substances, suspended and dissolved solids, fats, oil and grease, heavy metals, synthetic chemicals and pathogenic organisms are likely to be present in greywater. The organic fractions in greywater is around 30 per cent, while the nutrient fraction constitute $9-20$ per cent. Heavy metals, xenobiotic compounds, nitrates, phosphates, quaternary ammonium compounds (QUATS) were reported as contaminants in greywater. Most of these originate from body lotions, hair dyes and make-up materials. The presence of these compounds could harm ecosystems if not properly treated and disposed. The greywater needs to be treated and reused for the various household purposes, other than direct consumption.
\end{abstract}

Keywords: Greywater, heavy metals, xenobiotics, quaternary ammonium compounds

\section{Introduction}

Water, elixir of life, is the capital for social and economic development of human beings and for the preservation of healthy environment. India is blessed with the status of having about 4 per cent of World's freshwater resources; ranking in one among the top ten water wealth countries. Water resources of a Country are an indicator of the well being of its people. The amount of annual precipitation, availability of surface waters, groundwater potential is the factor that decides the water wealth of a Country. India's per capita surface availability of water is $1588 \mathrm{cu}$. $\mathrm{m}$, which is projected to reduce further down to 1401 and $1191 \mathrm{~m}^{3}$ by the years 2025 and 2050 (Kumar et al., 2005) ${ }^{[43]}$. The domestic water consumption in India accounts for about $17 \mathrm{cu}$. m (FAO, 2010) ${ }^{[27]}$ while the daily production of grey water in a average sized Indian family is estimated at 398.2 litres (Shaban and Sharma, 2008) ${ }^{[63]}$.

Wastewater generated from households is categorised in to two types, greywater and black water, greywater constituting the largest flow (Emmerson, 1998) ${ }^{[22]}$. Greywater refers to the household wastewater generated from showers, washing machines and bathroom sinks excluding toilet wastes and that it has low pathogenic and organic contaminants (WHO, 2006) ${ }^{[72]}$. Lazarova et al., (2003) ${ }^{[44]}$ estimated that greywater from residential apartment accounts for 50 - 70 per cent of wastewater generated.

\section{Characteristics of greywater}

The composition of greywater varies greatly according to its origin (i.e., bathroom, laundry or kitchen greywater) and is influenced by the water quality of the locality. A variety of contaminants including acidic and alkaline substances, suspended and dissolved solids, fats, oil and grease, heavy metals, synthetic chemicals and pathogenic organisms are likely to be present in grey water (Friedler, 2004; Erikssonand Donner, 2009) [29, 23]. Roeleveld and Zeeman (2006) ${ }^{[59]}$ reported that the organic fractions in greywater is around 30 per cent, while the nutrient fraction constitute $9-20$ per cent. 


\section{pH in greywater}

The $\mathrm{pH}$ in greywater to a large extent depends on the $\mathrm{pH}$ and alkalinity in the water supply and normally is within the range of 5-9. The $\mathrm{pH}$ in grey water is directly related to certain chemicals such as fabric softeners, bleaching agents and disinfectants (Eriksson et al., 2002) ${ }^{[25]}$. Braga and Varesche (2014) ${ }^{[13]}$ reported acidic $\mathrm{pH}$ (5.6) in greywater, but Friedler (2004) ${ }^{[29]}$ reported extreme alkaline $\mathrm{pH}$ (10) in greywaters of Israel. In general, wide variation in $\mathrm{pH}$, ranging from 6.4 to 8.1 was reported in greywater by many researchers (Burrows et al., 1991; Boal et al., 1996; Parjane and Sane, 2011) [14, 10, 56]. Greywater with most of its sources originating from the laundry will generally exhibit high $\mathrm{pH}$ due to the presence of alkaline materials used in detergents. The major chemical constituents found in greywater which is generated as a result of cleaning or washing activities are surfactant. These surfactants serve as the main active agent in most cleaning products. They can be either cationic or anionic in nature with a majority of cleaning and laundry products being anionic (Jakobi and Lohr 1987) ${ }^{[36]}$. Cationic surfactants are generally salt based, and they constitute a source of ammonium in the greywater. Other constituents found in greywater also include nitrates and phosphate which are reportedly from ammonium and cationic surfactants and laundry disinfectants respectively (Eriksson et al., 2002) ${ }^{[25]}$. Sodium which is also from cooking and preservation activities in the kitchen can also be found in appreciable levels. Sodium-based soaps also contribute significant quantity of sodium into greywater. Nutrients such as $\mathrm{N}$ and $\mathrm{P}$ are associated with kitchen and laundry activities. Greywater sources with high nutrients concentrations are mostly made up of a high fraction of kitchen and laundry sources (Boyjoo et al., 2013) ${ }^{[12]}$.

\section{Electrical conductivity in greywater}

Bodnar et al. (2014) ${ }^{[11]}$ reported conductivity values ranging from $0.52-1.27 \mathrm{dSm}^{-1}$ in greywater. Higher values of upto $4.7 \mathrm{dSm}^{-1}$ was obtained by Jamrah and Ayyash (2008) ${ }^{[37]}$. These variations would have been due to differential discharge of laundry, kitchen and floor washings at differential times. The detergents contains phosphates, sodium and potassium in their raw materials leads to the enrichment of the dissolved solids in the detergents leads to increase in the electrical conductivity. The ranges recorded for electrical conductivity in greywater is between 14 and $3000 \mu \mathrm{S} / \mathrm{cm}$ (Ciabatti et al., 2009; Prathapar et al., 2005) [16, 57]. Groundwater sources and water scarce areas are mostly associated with high electrical conductivity due to dissolved materials. Poor or old plumbing materials also contribute to the increase in electrical conductivity due to leaching into greywater sources.

\section{Solids in greywater}

The solid content of greywater in generally low, indicating that a large portion of the contaminants in dissolved form (Jayyousi, 2003) ${ }^{[39]}$. Suspended solid content varying from 15 $\mathrm{mg} \mathrm{L}^{-1}$ (Smith and Melhem, 2012) ${ }^{[66]}$ to $800 \mathrm{mg} \mathrm{L}^{-1}$ (Braga and Varesche, 2014) ${ }^{[13]}$ were reported in Brazil. The source of suspended solids is body care products, toothpaste, shaving waste, skin, hair, body fats and food particles and fibres from various textiles (Ghaitidak and Yadav, 2013) ${ }^{[31]}$.

Dissolved solids constitutes an important fraction of greywater. Abinaya and Loganath (2015) ${ }^{[1]}$ have reported TDS values of $712 \mathrm{mg} \mathrm{L}^{-1}$ to $990 \mathrm{mg} \mathrm{L}^{-1}$ in greywater collected from Chennai. Shegokar et al., (2015) ${ }^{[65]}$ reported $688.5 \mathrm{mg} \mathrm{L}^{-1}$ dissolved solids in Nagpur. Much higher values of $6888 \mathrm{mg} \mathrm{L}^{-1}$ was also reported in India (Sharma and Chhippa, 2014) ${ }^{[64]}$. Higher concentration of dissolved divalent ions such as calcium and magnesium in greywater imparts hardness to greywater (Lucy et al., 2011). Extremely high hardness of $7028 \mathrm{mg} \mathrm{L}^{-1}$ was reported in Jaipur by Sharma and Chhipa (2014) ${ }^{[64]}$.

The high temperatures may favour microbiological growth which is undesirable and may also cause precipitation of certain carbonates such as $\mathrm{CaCO}_{3}$ and other inorganic salts which become less soluble at high temperatures. The concentration of total suspended solids in greywater can range within 190-537 $\mathrm{mg} / \mathrm{L}$ as has been reported (Edwin et al. 2014; Oteng-Peprah et al., 2018) ${ }^{[54]}$.

Greywater with much of the water originating from the kitchen and laundry accounts for the relatively high values of total suspended solids (TSS), and this may be due to washing of clothes, shoes, vegetables, fruits, tubers and many others which may contain sand, clay and other materials that could increase TSS.

\section{Biological oxygen demand in greywater}

Biological Oxygen Demand (BOD) refers to the oxygen requirement in the greywater for microbial breakdown of organic compounds at a constant temperature. Smith and Melhem (2012) ${ }^{[66]}$ reported that the BOD in the greywater has very wider variations $\left(5 \mathrm{mg} \mathrm{L}^{-1}\right.$ to $\left.431 \mathrm{mg} \mathrm{L}^{-1}\right)$. In Chennai, Abinaya and Loganath (2015) ${ }^{[1]}$, who reported BOD range of $120 \mathrm{mg} \mathrm{L}^{-1}$ to $350 \mathrm{mg} \mathrm{L}^{-1}$. In Malaysia, identical result was recorded by Mohamed et al. (2012) ${ }^{[51]}$ with BOD ranging from $155 \mathrm{mg} \mathrm{L}^{-1}$ to $213 \mathrm{mg} \mathrm{L}^{-1}$ in raw greywater. The BOD values of $41.2 \mathrm{mg} \mathrm{L}^{-1}$ in Amman, Jordan (Jamrah et al., 2006) ${ }^{[38]}$ and $31.0 \mathrm{mg} \mathrm{L}^{-1}$ to $40.0 \mathrm{mg} \mathrm{L}^{-1}$ in Senegal (Sall and Takashi, 2006) ${ }^{[62]}$ were also reported. The main contributor to BOD in greywater is the dissolved organics and suspended food particles.

\section{Chemical oxygen demand in greywater}

Braga and Varesche (2014) ${ }^{[13]}$ reported COD values of 4800 $\mathrm{mg} \mathrm{L}^{-1}$ in Brazil of commercial laundry greywater. In contrast to this, Smith and Melhem (2012) ${ }^{[66]}$ reported lower COD values of $38 \mathrm{mg} \mathrm{L}^{-1}$ to $1843 \mathrm{mg} \mathrm{L}^{-1}$ in greywater. Jefferson et al. (2004) ${ }^{[40]}$ reported that greywater tends to contain fewer solids, as its contaminants are dissolved, which would keep the COD:BOD ratio around 4:1 in greywater. Variations in COD observed in the findings of Tilve (2014) ${ }^{[69]}$ reported COD variations between $383.57 \mathrm{mg} \mathrm{L}^{-1}$ and $434 \mathrm{mg} \mathrm{L}^{-1}$ in Nagpur. Similarly, in Chennai also, Abinaya and Loganath (2015) ${ }^{[1]}$ reported COD values ranging from $254 \mathrm{mg} \mathrm{L}^{-1}$ to $618 \mathrm{mg} \mathrm{L}^{-1}$ in greywater.

\section{Pathogens in greywater}

The coliforms represent the faecal contamination in the water. Winward et al. (2008) [74] reported that the fecal contamination of greywater is a common occurrence, creating the risk of a range of fecally transmitted pathogens. Coliform populations of $3 \times 103$ to $2.4 \times 107 \mathrm{CFU}$ per $100 \mathrm{ml}$ was reported by Eriksson et al. (2002) ${ }^{[25]}$. Rose et al. (1991) ${ }^{[60]}$ reported that families with children had high coliform count (3.2 x 105 and $1.5 \times 103 \mathrm{CFU}$ per $100 \mathrm{ml})$ in greywater as compared families without children $(6 \times 105$ and $80 \times 103$ CFU per $100 \mathrm{ml}$ ). In a study carried out in London, Birks et al. (2004) ${ }^{[9]}$ observed that fecal Enterococci were found in at least $70 \%$ of greywater tested.

Occurrence of other pathogenic bacteria, was also reported in greywater. Friedler et al. (2011) ${ }^{[30]}$ found skin pathogen 
(Pseudomonas aeruginosa), respiratory pathogen (Legionella pneumophila) and enteric pathogen (Escherichia coli) in greywater. Not only bacterial pathogens, but the pathogenic protozoan, Cryptosporidium sp. was also reported (Birks et al., 2004) ${ }^{[9]}$. Enteric pathogenic bacteria, such as Salmonella and Campylobacter, can be introduced by food handling in the kitchen (Cogan et al., 1999) ${ }^{[17]}$ in addition to that from the fecally derived matter.

\section{Fats, oil and grease in greywater}

The oil and grease is another important parameter in greywater as kitchen sinks and bathroom showers contribute to this pollutant. The concentration of oil and grease in an untreated domestic wastewater was $50 \mathrm{mg} \mathrm{L}^{-1}$ to $100 \mathrm{mg} \mathrm{L}^{-1}$ (Techobanglous et al., 2002) ${ }^{[68]}$. They block the filtration units and hinders with treatment efficiency. Oil and grease leads to formation of oil layer in water to cause reduction in light penetration, oxygen diffusion and photosynthesis by submerged plants (Mohammadi and Esmaelifar, 2005) ${ }^{[52]}$.

Some of the common conventional methods of oily wastewater treatment include flotation, gravitational methods, chemical treatment, biological treatment, dissolved air flotation (DAF) and use of membranes (Chowdhury et al, 2006) ${ }^{[15]}$. Oil droplets less than $50 \mu \mathrm{m}$ size have been removed by packed beds and dissolved air flotation (Rubio et al, 2002) [61]. Wastewaters containing fat and oils were traditionally treated physically, which is currently considered insufficient if the fat is in a dispersed form (El-Masry et al, 2004) [21]. Baig et al. (2003) [6], studied effectiveness of gravity separation and dissolved air floatation for the removal of oil and grease from industrial and domestic wastewaters and about $85 \%$ removal efficiency was achieved in removal as emulsified oil from the wastewaters.

\section{Other compounds}

Heavy metals, xenobiotic compounds, nitrates, phosphates, quaternary ammonium compounds (QUATS) were reported as contaminants in greywater (Donner et al., 2010) ${ }^{[19]}$. Most of these originate from body lotions, hair dyes and make-up materials. The presence of these compounds could harm ecosystems if not properly treated and disposed. XOCs are synthetic organic compounds that are present in household chemicals and pharmaceuticals such as bleaches, surfactants, softeners and builders and beauty products. XOCs can also be formed by partial modification of chemicals in chemical or biological treatment of greywater (Fatta-Kassinos et al., 2011) ${ }^{[28]}$. XOCs are recalcitrant to conventional treatment protocols and can easily accumulate in plants and animals and subsequently pose risks to the natural environment (FattaKassinos et al., 2011) ${ }^{[28]}$. Eriksson et al. (2002) ${ }^{[25]}$ identified 900 potential XOCs in greywater solely based on the ingredients of different cosmetics and detergents in Denmark. Le-Minh et al. (2010) ${ }^{[45]}$ identified the presence of antibiotics in greywater which may lead to proliferation of resistant bacteria strains.

\section{Treatment of Greywater}

The greywater needs to be treated and reused for the various household purposes, other than direct consumption. Greywater treatment is essentially required to reduce the organic load, nutrients and potent pathogenic microorganisms. Untreated greywater discharged in to any ecosystem is unsafe and hence proper treatment is required for safe discharge of greywater. A review of research works carried out on greywater treatment in India and elsewhere indicates that screening, aeration and filtration are essential components of the greywater treatment unit (Gross et al., 2007; March et al., 2004; Parjane and sane, 2011) ${ }^{[33,49,56]}$. Various materials like sand, pebbles, activated carbon, coconut shell, saw dust, charcoal, wood chips, bricks, rice husk (Parjane and sane, 2011) ${ }^{[56]}$ were tested by researchers to arrive at varied levels of treatment efficiency.

\section{Aeration}

Aeration allows for the intimate exposure of water and air by intensely mixing air and water so that chemical reactions occur between them to remove odourous compounds such as hydrogen sulfides and carbon dioxide (Fair et al., 1971) ${ }^{[26]}$. Aeration also helps supply oxygen for microbial remediation of wastewaters. Improved aeration system like fine bubble aeration are an excellent way to improve the oxygen transfer efficiency (Taricska et al., 2009) [67]. Various types of diffused aerators like coarse bubble diffusers, fine bubble diffusers and submerged jet aerators are being used.

\section{Filtration}

Filtration is a pollutant removal mechanism that includes screening, adsorption and biodegradation. Filtration removes solid materials like hair, fabric pieces and food particles from greywater. Ludwig (2000) ${ }^{[48]}$ proposed the use of natural mulch basin filled with stones and organic mulch (leaves, tree bark etc) to treat greywater. Alaziz and Al-saqer (2014) ${ }^{[3]}$ proposed a filtration system consisting of shallow layers of stone, medium gravel, and pea gravel beneath a deep layer of sand and multimedia filters. A combination of coarse and fine filter was recommended by Hodgson (2012) ${ }^{[35]}$, to achieve 15 $\pm 10 \%$ total organic carbon (TOC) removal and $1 \pm 7 \%$ turbidity reduction in coarse filters while fine filter achieved $31 \pm 17 \%$ and $13 \pm 11 \%$, reduction in TOC and turbidity respectively.

Li et al. (2008) ${ }^{[46]}$ studied an ultrafiltration membrane system that treated greywater from all household sources (including laundry machines, dishwashers and kitchen sinks in addition to baths, showers and hand basins) and the performance is fair. The key principle behind filtration is blocking of impurities from reaching downstream by adsorption and absorption. Adsorption is a process by which the impure constituents are eliminated by physically or chemically binding it to on the surface of suitable adsorbents. In his review on greywater, Katukiza et al. (2013) ${ }^{[42]}$ mentioned physical adsorption using locally available filter media is an effective mean to remove ammonia, phosphorous, cations and even partial bacterial load from greywater. In contrast, absorption is a process by which impurities are assimilated by the adsorbent (Watson, 1999) ${ }^{[71]}$.

\section{Sand filters}

The sand filtration is a proven method for wastewater purification and is well suited for greywater treatment. Coarse sand, fine sand, beach sand, river sand, silica sand etc are some sand types attempted by scientists to treat greywater. Fine sand filter of $0.3 \mathrm{~mm}$ size with respective values of 1.82 , $1.48 \mathrm{Mg} \mathrm{m}^{-3}$ and 0.4 percent for uniformity coefficient, specific density and porosity (Govahi., 2014) ${ }^{[32]}$. Other sizes tried include $0.7,1.3$ and $2.5 \mathrm{~mm}$, either as single layer or in multiple layers.

Size alone does not decide the treatment efficiency. The purification performance of sand filtration system is also dependent on hydraulic loading, sand texture and surface chemistry of the sand grains. Typical loadings in the range of 
2 - $10 \mathrm{~cm}$ per day were recommended for effective performance, with BOD removal of more than 80 per cent (Jenssen and Siegrist, 1990) ${ }^{[41]}$. Sand filters are not only used during primary treatment, but are also occasionally used as effluent polishers during tertiary treatment to remove residual suspended material and provides a physical matrix for bacterial decomposition of nitrogenous material, including ammonia and nitrates, into nitrogen gas. Besides the physical filtration through the sand, an active biofilm develops. It is attached to the sand particle surfaces and mineralize organic matter from the wastewater (Rodgers et al., 2005) ${ }^{[58]}$.

\section{Activated charcoal}

Activated charcoal refers to the charcoal that is treated with oxygen to open up millions of tiny pores between the carbon atoms. These active pores adsorb odorous and coloured substances from gases or liquids. Most activated carbons are made from raw materials such as nutshells, wood, coal and petroleum. Typical surface area for activated carbon is approximately 1,000 square meters per gram $\left(\mathrm{m}^{2} / \mathrm{gm}\right)$. Berger (2012) ${ }^{[8]}$ reviewed the performance of activated carbon in removing pollutants from greywater and he concluded that activated carbon showed superior performance in reducing organics (upto $97 \%$ reduction in COD and $94 \%$ reduction in BOD); surfactants (99\% reduction), and total phosphorous (91\% reduction). Activated carbon also reduced total nitrogen by $98 \%$ (Dalahmeh et al., 2012) ${ }^{[18]}$. Granular activated carbon (GAC) filters also have more wider applicability in water treatment units to adsorb different organic macropolutants, disinfectant by-products, as well as odour and taste compounds from water (Velten, 2008) ${ }^{[70]}$.

\section{Zeolite}

Zeolites refer to aluminosilicate minerals which are porous in nature, which can accommodate cations, by holding them or exchanging them in their active sites. Zeolitesare considered excellent trappers of waste products and heavy metals because of its chemical composition and specific lattice structure (Beltcheva et al.,2015) ${ }^{[7]}$. A very unique property of zeolite is that they are highly selective towards cations and many experiments conducted on this aspect proved positive for removal of copper $\left(\mathrm{Cu}^{2+}\right)$, manganese $\left(\mathrm{Mn}^{2+}\right)$ and $\mathrm{Zinc}\left(\mathrm{Zn}^{2+}\right)$, which are common contaminants in water (Margeta et al., 2013) ${ }^{[50]}$.

Both natural and synthetic zeolites are porous materials, able to adsorb molecules of appropriate cross-sectional diameter and because of this property, zeolites are used for wide range of industrial and agricultural applications (Mumpton,1999) ${ }^{[53]}$. Assayed et al. (2013) assessed the efficiency of zeolites in greywater treatment in combination with sand bed filter. The treatment efficiency as reported by them was $82-87 \%$ for $\mathrm{COD} ; 85-100 \%$ for phosphates $\left(\mathrm{PO}^{4-}\right)$; $64-75 \%$ nitrates for $\left(\mathrm{NO}^{3-}\right)$ and $58-89 \%$ for turbidity. The process efficiency for ammonium removal from greywater using zeolite was $97 \%$ as reported by Widiastuti et al.,(2011). However, he notified that the good performance of zeolite filters depend on contact time, zeolite loading, initial ammonium concentration and $\mathrm{pH}$ value. Hydrophobic zeolite pellets were reported to adsorb dissolved organic compounds (Hansen and Davies., 1994).

\section{Efficiency of different filter models in removing pollutants from Greywater}

Different filter based models have been tried by researchers across the globe to treat greywater. Because of the lesser concentration of conventional pollutants, filtration is foreseen as a low cost option for treating greywater.

Assayed et al. (2015) ${ }^{[4]}$ developed a new treatment method called 'Drawer Compacted Sand Filter (DCSF)' designed to prevent clogging problem, usually encountered in conventional filters. The results showed that DCSF removed $78-96 \%$ of BOD5, COD and $69-98 \%$ of TSS. Even earthworms have also been employed for greywater treatment. In Burkina Faso, a West African country, Adunga et al. (2015) ${ }^{[2]}$ employed sand, fine saw dust and vermifilters for greywater treatment and reported that the removal efficiencies of BOD and COD were 25-30\% higher than control. However, they could not record any significant removal of TSS and coliforms. Not only filter beds based sysem, but direct and in-situ application of greywater was tried by Pandey et al. (2011) ${ }^{[55]}$ in India. They tried vegetations as filer system in soil using four species viz., Eucalyptus hybrid, Populus deltoids, Salix albaand Melia azedarach and the study revealed that total NPK removal from greywater was 50,34 and $15 \%$ respectively, whereas BOD and COD reduction achieved was 60 and $46 \%$ respectively. Eucalyptuswas found to be the better among the four test crops. Some common greywater treatment methods and short comings advanced greywater treatment systems (Table 1). Assayed et al. (2015) ${ }^{[4]}$ compiled the problems encountered by researchers.

Table 1: Problems encountered with advanced greywater treatment systems

\begin{tabular}{|c|c|}
\hline Treatment method & Shortcomings \\
\hline Sequencing batch reactor (SBR) & $\begin{array}{cc}\bullet & \text { Requires highly skilled operators } \\
\bullet & \text { Continuous power supply needed } \\
-\quad \text { Dissolved oxygen levels and Mixed Liquor Suspended Solids (MLSS) concentration should be } \\
\text { maintained uniformly. }\end{array}$ \\
\hline $\begin{array}{l}\text { Upflow anaerobic sludge blanket } \\
\text { (UASB) }\end{array}$ & $\begin{array}{c}-\quad \text { Achieves less than } 70 \% \text { of COD removal } \\
\bullet \quad \text { Inadequate for } E \text {. coli reduction. } \\
\text { - Strict temperature maintenance for the anaerobic bacteria, which is not easily achievable in many } \\
\text { locations. }\end{array}$ \\
\hline $\begin{array}{l}\text { Membrane bioreactor technology } \\
\text { (MBR) }\end{array}$ & $\begin{array}{c}\bullet \quad \text { High operational and investment cost } \\
\text { - } \quad \text { Not suitable for greywater treatment in poor urban areas }\end{array}$ \\
\hline Constructed wetland (CWT & $\begin{array}{c}\quad \text { Large area of land required } \\
-\quad \text { Emission of bad odors } \\
\text { Excavation difficulties and other labour works }\end{array}$ \\
\hline $\begin{array}{l}\text { Rotating biological contactor } \\
\text { (RBC) }\end{array}$ & $\begin{array}{l}\text { - Proven and effective results under laboratory conditions } \\
\text { - Insufficient information on their suitability under field conditions }\end{array}$ \\
\hline
\end{tabular}




\section{Conclusion}

The review states that the various characteristics features of greywater, treatment methods and reuse ways in India. A wide variation in characteristics of greywater is mainly due to quality of water use in different domestic activities to fulfill the human needs. The available technologies have been developed to treat or remove specific pollutants and not offer a full treatment of the greywater. However, the implementation of household level greywater treatment system that target a certain reuse option and thereby increase the number of households to implement the treatment options for grey water recycling.

\section{References}

1. Abinaya MP, Loganath R. Reuse of grey water using modified root zone system. Int. J. Eng. Resour. \& Technol. 2015; 4(2):454-458.

2. Adunga AT, Andrianisa HA, Konate Y, Ndiaye A, Maiga AH. Performance comparison of sand and fine sawdust vermifilters in treating concentrated grey water for urban poor. Environ. Technol. 2015; 36(21):2763-2769.

3. Al-Saqer. Filtration system for greywater recycling. Int. J. Eng Res \& Appl. 2014; 4(3):208-215.

4. Assayed A, Chenoweth J, Pedley S. Assessing the efficiency of an innovative method for onsite greywater treatment: Drawer compacted sand filter - A case study. Ecol. Eng. 2015; (81):525-533

5. Assayed A, Hatokay Z, Al - Zoubi R, Azzam S, Bailat M, Al - Ulayyan A et al. On - site rainwater harvesting to achieve household water security among rural and periurban communities in Jordan. Resour. Conser. \& Recycling. 2013; 73:72-77.

6. Baig AM, Mir M, Bhatti I, Baig MA. Removal of oil and grease from industrial effluents. EJEAFChe., 2003; 2(5):577-585.

7. Beltcheva MI, Metcheva RI, Topashka MI, Ancheva N, Popov S, Teodorova JA. Heredia - Rojas and F. Rodriguez. Zeolites versus Lead toxicity. J. Bioequiv. Availab. 2015; 7:1-3.

8. Berger C. Biochar and Activated Carbon Filters for Greywater Treatment: Comparison of Organic Matter and Nutrients Removal. Swedish University of Agricultural Sciences, Uppsala. 2012, 41.

9. Birks CRJ, Hills S, Hobson R. Microbiological water quality in a large in- building, water recycling facility. Water Sci. \& Technol. 2004; 50(2):165-72.

10. Boal CD, Eden RE, McFarlane S. An investigation into greywater reuse for urban residential properties. Desalination. 1996; 106:391-397.

11. Bodnar I, Szabolcsik A, Baranyai E, Uveges A, Boros N. Qualitative characterization of household greywater in the Northern great plain region of Hungary. Environ. Eng. and Manage. J. 2014; 13(11).

12. Boyjoo Y, Pareek VK, Ang M. A review of greywater characteristics and treatment processes. Water Sci. Technol. 2013; 67:1403-1424.

13. Braga JK, Varesche MBA. Commercial laundry water characterization. Am. J. Anal. Chem. 2014; 5:8-16.

14. Burrows WD, Schmidt MO, Carnevale RM, Shaub SA. Nonpotable reuse: development of health criteria and technologies for shower water recycle. Water Sci. Technol. 1991; 24(9):81-88.

15. Chowdhury AJK, Alam MZ, Shahlizah SH. Isolation, purification and screening of fungal strain for effective bioconversion of palm oil mill effluent. In: Proceedings of the 1st International Conference on Natural Resources Engineering \& Technology. Putrajaya, Malaysia, 2006, $167-75$

16. Ciabatti I, Cesaro F, Faralli L, Fatarella E, Tognotti F. Demonstration of a treatment system for purification and reuse of laundry wastewater. Desalination. 2009; 245:451-459.

17. Cogan TA, Bloomfield SF, Humphrey TJ. The effectiveness of hygiene procedures for prevention of cross-contamination from chicken carcases in the domestic kitchen. Lett. Appl. Microbiol. 1999; 29:354-8

18. Dalahmeh SS, Pell M, Vinneras B, Highlander LD, Oborn I, Jonsson H. Efficiency of bark activated charcoal, foam and sand filters in reducing pollutants from greywater. Water, air \& soil pollut. 2012; (2):1-15.

19. Donner E, Eriksson E, Revitt DM, Scholes L, Holten L, Lutzhoft HC, Ledin A. Presence and fate of priority substances in domestic greywater treatment and reuse systems. Sci. Total Environ. 2010; 408(12):2444-2451.

20. Edwin GA, Gopalsamy P, Muthu N. Characterization of domestic gray water from point source to determine the potential for urban residential reuse: a short review. Appl. Water Sci. 2014; 4:39-49.

21. El-Masry MH, El-Bestaway E, El-Adl NI. Bioremediation of vegetable oil and grease from polluted wastewater using a sand biofilm system. World J. Microbiol. \& Biotechnol. 2004; 20:551-557.

22. Emmerson G. Every Drop is Precious: Greywater As An Alternative Water Source. Research bulletin No 4/98 of the Queensland Parliamentary Library, Brisbane, 1998, 47.

23. Eriksson E, Donner E. Metals in greywater: Sources, presence and removal efficiencies. Desalination, 2009; 248(1-3):271-278.

24. Eriksson E, Donner E, Ledin A. Presence of selected priority and personal care substances in an onsite bathroom greywater treatment facility. Water Sci. Technol. 2010; 62(12):2889-2898.

25. Eriksson E, Auffarth K, Henze M, Ledin A. Characteristics of grey wastewater. Urban Water. 2002; 4(1):85-104.

26. Fair GM, Geyer JC, Okun DA. Elements of Water Supply and Wastewater Disposal. John Wiley and Sons, Inc. New York. 1971, 477.

27. FAO. Global water statistics of the Land and Water Division of the Food and Agricultural Organisation, United Nations, 2010. http://www.fao.org/nr/water.

28. Fatta-Kassinos D, Kalavrouziotis IK, Koukoulakis PH, Vasquez MI. The risks associated with wastewater reuse and xenobiotics in the agroecological environment. Sci Total Environ. 2011; 409:3555-3563.

29. Friedler E. Quality of individual domestic greywater streams and its implication for on -site treatment and reuse possibilities. Environ. Technol. 2004; 25:997-1008.

30. Friedler E, Yardeni A, Gilboa Y, Alfiya Y. Disinfection of greywater effluent and regrowth potential of selected bacteria. Water Sci. \& Technol. 2011; 63(5):931 940.

31. Ghaitidak DM, Yadav KD. Characteristics and treatment of greywater - A review. Environ. Sci. and Pollut. Res., 2013; 20:2795-2809.

32. Govahi S. Studying of treatability of gray water using slow sand Filter. Bull. Environ., Pharmacol. \& Life Sci. 2014; 3(6):214-218.

33. Gross A, Kaplan D, Baker K. Removal of chemical and microbiological contaminants from domestic greywater 
using a recycled vertical flow bioreactor (RVFB). Ecol. Eng. 2007; 31:107- 114.

34. Hansen BR, Davies SH. Review of potential technologies for the removal of dissolved components from produced water. Chem. Eng. Res. Des. 1994; 72:176-188.

35. Hodgson B. Development of a cost effective and energy efficient treatment system for graywater reuse for toilet flushing at the multi-residential scale. M.Sc Civil and Environmental Engineering Thesis, Colorado State University, Fort Collins, Colorado, 2012.

36. Jakobi G, Lohr A. Detergents and textile washing. VCH, Weinheim, 1987.

37. Jamrah A, Ayyash S. Grey water generation and characterization in major cities in Jordan. Jo. J. civil Eng., 2008; 2(4):376 -390.

38. Jamrah A, Al-Omari A, Al-Qasem L, Abdel Ghani N. Assessment of availability and characteristics of greywater in Amman. Water Int., 2006; 2(31):210-220.

39. Jayyousi A. Greywater reuse: towards sustainable water management. Desalination., 2003; 156(1-3):181-192.

40. Jefferson B, Palmer A, Jeffery P, Stuetz R, Judd S. Greywater characterisation and its impact on the selection and operation of technologies for urban reuse. Water Sci \& Technol. 2004; 50(2):157-164.

41. Jenssen PD, Siegrist RL. Technology assessment of wastewater treatment by soil infiltration systems. Wat. Sci. Technol., 1990; 22(3, 4):83-92.

42. Katukiza AY, Ronteltap M, Niwagaba CB, Kansimme F, Lens PNL. Grey Water Characterization and Pollutant Loads in Urban Slum. Int. J. Environ. Sci. \& Technol. 2013; 10:1-14.

43. Kumar R, Singh RD, Sharma KD. Water resources of India. Curr. Sci., 2005; 89(5):1518-1527.

44. Lazarova V, Hills S, Birks R. Using recycled water for non-potable, urban uses a review with particular reference to toilet flushing. Water Sci. \& Technol., 2003; 3(4):69-77.

45. Le-Minh N, Khan SJ, Drewes JE, Stuetz RM. Fate of antibiotics during municipal water recycling treatment processes. Water Res. 2010; 44:4295-4323.

46. Li F, Behrendt J, Wichmann K, Otterpohl R. Resources and Nutrients Oriented Greywater Treatment for NonPotable Reuses. Water Sci. \& Technol. 2008; 57(12):1901-7.

47. Lucy A, Juliet C. Meena P. Overview of Greywater Systems to Aid Sustainable Water Management. Pacific Institute, California. 2010, 40.

48. Ludwig A. Create an Oasis with Greywater. Oasis design, California, 2000, 155.

49. March JG, Gual M, Orozco F. Experiences on greywater reuse for toilet flushing in a hotel (Mallorca Island, Spain). Desalination, 2004; 164(3):241-247.

50. Margeta K, Natasa ZL, Mario S, Anamarija F. Natural Zeolites in Water Treatment "Disinfection of Greywater Effluent and Regrowth Potential of Selected Bacteria." Water Sci. \& Technol. 2013; 63(5):931-940.

51. Mohamed HA, Rahman RA, Suja FB, Mahmud M, Abdulah SMS. Greywater Treatment using GAC biofilm reactor and Sand filter system. Aus. J. Basic \& Applied Sci. 2012; 6(3):283-292.

52. Mohammadi T, Esmaelifar A. Wastewater treatment of a vegetable oil factory by a hybrid ultrafiltration-activated carbon process, J. of Membrane Sci., 2005; 254:129-137.
53. Mumpton FA. Uses of natural zeolites in agriculture and industry. Proc. Natl. Acad. Sci., USA. 1999; 96:34633470.

54. Oteng-Peprah M, de Vries NK, Acheampong MA. Greywater characterization and generation rates in a peri urban municipality of a developing country. J. Environ. Manage. 2018; 206:498-506.

55. Pandey A, Mohinisingh R, Srivastava K, Vasudevan P. Pollutant removal potential, growth and nutritional changes of short rotation woody crops in greywater vegetation filter system. J. sci. and Ind. Res. 2011; 70:610-615.

56. Parjane PS, Sane MG. Performance of greywater treatment plant by economical way for Indian rural development. Int. J. Chem Tech Res., 2011; 3(4):18081815.

57. Prathapar SA, Jamrah A, Ahmed M, Al Adawi S, Al Sidairi S, Al Harassi A. Overcoming constraints in treated greywater reuse in Oman. Desalination. 2005; 186:177-186.

58. Rodgers M, Healy MG, Mulqueen J. Organic carbon removal and nitrification of high strength wastewaters using stratified sand filters. Water Res. 2005; 39(14):3279-3286.

59. Roeleveld KK, Zeeman G. Anaerobic treatment in decentralised and source-separation-based sanitation concepts. Rev. in Env.Sci. \& Bio-Technol. 2006; (5):115139.

60. Rose JB, Gwo-shing S, Gerba CP, Sinclair NA. Microbial quality and persistence of enteric pathogens in graywater from various household sources. Water Res., 1991; 25(1):37-42.

61. Rubio J, Souza ML, Smith RW. Overview of flotation as a wastewater treatment technique. Minerals Eng. 2002; 15:139-155.

62. Sall O, Takashi Y. Physical, chemical and biological characteristics of stored greywater from unsewered suburban Dakar in Senegal. Urban Water 2006; (3):153164.

63. Shaban A, Sharma RN. Water consumption pattern in domestic households in major Indian cities. Econ. \& Political Weekly. 2008, 12.

64. Sharma H, Chhipa RC. An opportunity for water conservation: A Grey water (cloth washings) and its application. Int. J. Res. Aspects of Eng. \& Manage., 2014; 1(2):91-94.

65. Shegokar VV, Ramteke DS, Meshram PU. Design and treatability studies of low cost greywater treatment with respect to recycle and reuse in rural areas. Int. J. of Curr. Microbiol \& Appl. Sci., 2015; 4(8):113-124.

66. Smith E, Melhem KB. Grey water characterization and treatment for reuse in an arid environment. Water Sci. \& Technol. 2012; 66(1):252- 255.

67. Taricska J, Chen JP, Hung YT, Wang L, Zou SW. Surface and spray aeration, - Biological Treatment Processes In: Wang, L., Pereira, N., Hung, Y.-T. (Eds.). Humana Press, 2009, 151-206.

68. Techobanglous GB, Franklin L, Stenset HD. wastewater engineering. metcalf and eddy Inc. 2002, 1848.

69. Tilve MM. Seasonal variation in greywater quality for a real life system. Int. J. Res. Eng. \& Technol. 2014; 3(3):768-770.

70. Velten S. Adsorption capacity and biological activity of biological activated carbon filters in drinking water 
treatment. ETH. 2008. http://dx.doi.org/10.3929/ethz-a005820821

71. Watson JS. Separation methods for waste and environmental applications. marcel dekker Inc. New York, 1999, 595.

72. WHO, 2006. Report of the first consultative workshop on the WHO/IDRC project. Non-treatment options for safe wastewater use in poor urban communities, 4-7 December 2006, Accra, Ghana, 53.

73. Widiastuti $\mathrm{N}$, Wu HMA, Zhang D. Removal of ammonium from grey water using natural zeolite. Desalination. 2011; 277:15-23.

74. Winward G, Lisa P, Avery M, Williams RF, Pidou M, Jeffrey $\mathrm{P}$ et al. A study of the microbial quality of grey water and an evaluation of treatment technologies for reuse. Ecol. Eng. 2008; 32(2):187-197. 